\title{
Fiscal Policy Measures of Air Protection: Ukrainian Realities and the EU Experience
}

\author{
By Volodymyr Kurylo ${ }^{1}$, Yevheniia Duliba ${ }^{2}$, Inna Kurylo ${ }^{3}$, Viktor Mushenok ${ }^{4}$
}

\begin{abstract}
Nowadays environmental protection and the rational use of natural resources have become priorities of the state-building strategy in almost all developed countries of the world. Effective financing of these activities is required for the development and adoption of national targeted, local programs for environmental protection, for the sustainable development of society, for the rational use and reproduction of natural resources. The article is devoted to the research of the current tendencies of the use of fiscal policy measures in the implementation of the national environmental policy in the sphere of atmospheric air protection in Ukraine. The ways of improvement of environmental taxation and development of the main ways of development and expansion of the system of ecological taxation and ecological governance in Ukraine were discovered.
\end{abstract}

Keywords: atmospheric air, environmental air safety, fiscal policy, environmental taxation, implementation of the national environmental policy,

\section{Introduction}

The economic growth of each state inevitably leads to an increase in the use of natural resources and wastes of consumption, and increases the anthropogenic load on the environment. Our environment is constantly changing. However, as our environment changes, so does the need to become increasingly aware of the problems that surround it.

The processes of globalization and social transformation have increased the priority of environmental protection, the desire to achieve ecological balance and ensure the sustainable development of the country.

For a long time, Ukraine's economic development was accompanied by an unbalanced exploitation of natural resources, a low priority of environmental protection, which made it impossible to achieve balanced development and led to numerous environmental problems. Subordination of environmental priorities to economic feasibility, failure to take into account environmental impacts in legislative and regulatory acts, inefficient public administration in the field of environmental protection and natural resource

\footnotetext{
| ${ }^{1}$ D.Sc (Law), professor, Head of the Department of Administrative and Financial Law of the National University of Life and Environmental Sciences of Ukraine, Ukraine

${ }^{2}$ D.Sc (Law), associate professor, professor of Criminal Law and Justice Department at Private Institution of Higher Education "International University of Economics and Humanities named after Academician Stepan Demianchuk", Rivne, Ukraine

${ }^{3}$ D.Sc (Law), associate professor, professor of the Department of International Law and Comparative Law of the National University of Life and Environmental Sciences of Ukraine, Ukraine

${ }^{4}$ D.Sc (Law), associate professor, professor of the Department of General Legal Disciplines of Kyiv National 
management, insufficient funding from state and local budgets for environmental measures, funding for such measures led to increased technogenic load on the ecological system, to the gradual destruction of the environment its natural environment. Understanding the importance of responsible consumption and production in the country necessitates the development and implementation of sound environmental policies and adoption of measures to ensure for good environmental governance in a country with sufficient funding of environment protection activities.

\section{Discussion}

Environmental management is crucial for the growth of every country's economy for a balanced development. Modern economic development sometimes disrupts nature's delicate balance. The extent of environmental pollution caused by humans is already so great that some scientist question whether the Earth can continue to support life unless immediate corrective action is taken) (Hossain et al. 2014).

The environmental situation continues to deteriorate, thus creating a real threat to humanity's existence. Such global aggravation of the environmental situation in the world has led to the need for a radical rethinking of the goals and priorities of the further development of society in the direction of harmonization of interactions between society and nature.

Atmospheric air is one of the environmental components that determines the state of human health. Despite the fact that in the EU today, the Air Quality Directive (2008/50 / EC) sets and regulates legally binding limits and targets for concentrations of major air pollutants (Directive 2008/50/EC of the European Parliament and of the Council, 2008). Air pollution is a transboundary problem crosses national borders so it is a matter of international concern. Air pollution affects all living beings who are forced to migrate in search of a cleaner habitat, which causes ecosystem imbalance. Air pollution has negative impacts on ecosystem health, with further consequences for global biodiversity, and thus for communities. Biodiversity loss threatens human populations reliant on a range of services including food production and human health needs. In addition to natural ecosystems, air pollution threatens global crop yields, with consequences for sustainable agriculture. These negative impacts can threaten food security and nutrition. Many pollutants can cause the recession or corrosion of materials used in historic buildings, monuments, and artworks. For example, limestone is vulnerable to erosion due to acid rain, and other materials can become discolored from interaction with sulfate deposition. Corrosion of copper and bronze is also caused by air pollution (Di Turo et al., 2016).

Analysis of perspective directions of cooperation between Ukraine and the EU in the field of ecology makes it possible to identify the most promising areas of this cooperation, as well as the most relevant for the harmonization of Ukrainian legislation. These include the use of water resources, in the first place, of transboundary rivers; protection of atmospheric air purity and problems of prevention, assessment and elimination of harmful effects on the environment (Gulak et al. 2019).

Regardless of the source of air pollution, environmental pollution continues to be a 
major issue for human health. In 2019, air pollution is considered by WHO as the greatest environmental risk to health. Microscopic pollutants in the air can penetrate respiratory and circulatory systems, damaging the lungs, heart and brain, killing 7 million people prematurely every year from diseases such as cancer, stroke, heart and lung disease. Around $90 \%$ of these deaths are in low- and middle-income countries, with high volumes of emissions from industry, transport and agriculture, as well as dirty cookstoves and fuels in homes) (WHO, 2019).

The economy of Ukraine is characterized by giving advantages to the development of raw materials, mining, metallurgical, mining and chemical industries, the introduction and increasing the share of resources and energy-intensive technologies in industry and agriculture.

Outdated industrial equipment and technologies causes atmospheric air pollution and catastrophic emissions. In addition, the years of uncontrolled exploitation of natural resources have led to the fact that in many parts of Ukraine air pollution is ten times higher than the limit values. Along with this, cars with increasing numbers each year also have a significant impact on air pollution.

Air pollution in Ukraine, as well as in many countries of the world, is mainly caused by economic activity. In Ukraine, the main sources of air pollution are concentrated in four sectors of economic activity such as: 1) energy (exploration and production of primary energy sources; conversion of primary energy sources into more usable forms; transportation, stationary and mobile fuel use); 2) industry; 3) agriculture, forestry and other land uses (CO2 emissions and sequestration in agricultural and forestry processes); 4) waste management (disposal, biological treatment, incineration of solid waste, wastewater treatment). In addition, air pollution can also be caused with some domestic household activities like heating. Statistics show that emissions of pollutants and greenhouse gases by fuels and energy companies account for about $40 \%$ of emissions from all sectors of the economy and 58\% from stationary sources of pollution. According to the Ministry of Energy and Environment of Ukraine only in 2018, 2.588 million tons of pollutant emissions into the environment were produced, 952.136 million m3 of discharges, 352.333 million tons of waste generation (Ministry of EEPU, 2019).

Due to the difficult situation in Ukraine, the issue of air pollution is not a priority. The constant deterioration of the environment has led to Ukraine ranked 109th out of 180 countries worldwide by the Environmental Performance Index 20189 (EPI report, 2018). This, in turn, requires Ukraine to take measures to preserve and restore the environment.

The changes in the natural system inevitably result in the changes in our society. Stringent national air pollution regulations, as well as compliance with strong regional agreements, are key tools to improve environmental performance on air pollution. In 2010 the European Economic Development Strategy «EUROPE 2020 A strategy for smart, sustainable and inclusive growth" pays considerable attention to the implementation of the idea of more rational use of natural resources, improvement of the ecological situation, development of new environmentally friendly technologies with the aim of reducing greenhouse gas emissions by at least 20\% compared to 1990 levels or by $30 \%$, if the conditions are right; reducing increase the share of renewable energy 
sources in our final energy consumption to $20 \%$; and a $20 \%$ increase in energy efficiency (European Commission, 2010).

The development of the energy sector and focusing on its greening, improvement of the environmental situation with regard to electricity, energy efficiency related to them, requires the state to take measures to integrate Ukraine's energy system with the continental European energy system and to adapt it to the energy and environmental legislation of the European Union. In this context, it is important to formulate adequate funding for energy and environmental policies and create the conditions for environmental security, which implies a dramatic increase in energy efficiency of national production and the widest possible use of renewable sources.

The difficult environmental situation necessitates the improvement of environmental mesuares through, among fiscal policy. Fiscal policy serves to ensure the stability and sustainability of the national economy, to achieve the maximum possible well-being of society by creating the proper conditions for the socio-economic system. Fiscal policy measures implemented in the environmental field include: environmental taxation, compensation for losses caused by violation of the legislation on the protection of the atmospheric air; granting to enterprises, institutions, organizations and citizens - subjects of business activity of tax, credit and other privileges in case of introduction of lowwaste, energy and resource-saving technologies, application of measures on regulation of activity affecting climate, implementation of other environmental measures with the purpose of reduction emissions of pollutants and reduction of levels of influence of physical and biological factors on atmospheric air; government involvement in financing environmental events and building environmental facilities (On Air Protection, 1992).

It is fiscal policy that allows you to establish the taxes, spend the state budget to solve problems of Prevention of Air Pollution and air protection.

Environmental taxation is the most important incentive for sustainable use of the environment and consists in establishing a direct correlation between the amount of tax deductions and the degree of negative effects on the environment and natural resources as a result of the activities of economic entities. It is environmental taxes can contribute to a healthier planet and healthier people, and promote more responsible environmental behavior among citizens.

EU environment policy rests on the principles of precaution, prevention and rectifying pollution at source, and on the 'polluter pays' principle. However, revenue from environmental taxes is still low in most countries and still not in proportion with economic growth rates. For example, in 2018, total revenue from environmental tax in the 28 countries EU members (revenue from environmental taxes collected by governments of all EU Member States) was $€ 381.3$ billion; this figure is $2.4 \%$ of the EU's gross domestic product (GDP) and $28 \%$ and $6.1 \%$ of the government's total EU tax and social contribution (Eurostat, 2018).

The experience of EU countries shows that the reasons for the effectiveness of environmental taxes for pollution in EU countries are high rates, which are aimed at making it more profitable for businesses to take environmental measures rather than to pollute them.

It is through that the investment and innovation activities of economic entities in the field of environmental protection can be ensured: stimulate them to innovate and invest 
in renewable energy sources and alternative fuels, efficient use of fuel and energy resources, implementation of energy saving measures; increasing the share of renewable energy sources and alternative fuels in the energy balance of the country; adjusting consumer demand for environmentally friendly and harmful products, their supply from manufacturers; efficient use of natural resources; financing of environmental funds, etc. The purpose of the use of budget is to preserve natural ecosystems maintain their integrity, ensure ecological security and the balanced scorecard system for the sustainable development of society. The main feature of tax environmental fiscal instruments is that the funds collected in this way are transferred to the budget accounts of the appropriate level (state or local) and are used to finance environmental problems and compensation for losses.

The amount of funds that will be allocated from the budgets of different levels to finance environmental measures depends on the revenues of environmental taxes, and their amount should be sufficient to implement measures to compensate for the environmental damage caused by pollutants. Thus, environmental taxes serve not only a fiscal function but also a compensatory one, meaning that the tax revenues are several times higher than the state expenditures on environmental protection measures.

For Ukraine, financing of environmental protection measures is carried out at the expense of the State Budget of Ukraine and local budgets, funds of enterprises, institutions and organizations, environmental protection funds, voluntary contributions and other funds. State and local budget funds are generated through environmental taxes, as well as fines and claims levied for compensation for damage to the environment, caused as a result of violation of environmental legislation and targeted and other voluntary contributions from businesses, institutions, organizations and citizens.

According to the report of the Accounting Chamber of Ukraine in 2018 the environmental tax in the amount of UAH 2.266 billion was paid to the consolidated state budget of Ukraine. With that amount revenues of the emissions from pollutants into atmospheric air by stationary sources of pollution amount of UAH 1.161 billion. The State Environmental Protection Fund received 132, 1 thousand UAH for environmental (The State Treasury Service of Ukraine, 2018). What is important, however, according to this report of the Accounting Chamber of Ukraine in 2018 on the implementation of environmental measures spent only 522 million UAH. In addition, environmental measures financed from the state budget, in addition to the protection of atmospheric air, include the protection and rational use of water, plant resources; fauna; conservation of the nature reserve fund; rational use and storage of production and household waste; implementation of activities in the field of science, information and education, as well as training, conducting environmental expertise, organization of work, ensuring participation in the activities of international environmental organizations, implementation of an economic mechanism for environmental protection (Some Issues of Implementation of the Financing Agreement on the Support to the Implementation of the National Environmental Policy Strategy of Ukraine, 2011).

It can be stated that the financing of environmental protection measures for the air protection in Ukraine is inadequate and also neither sufficient nor equitable. The atmospheric air protection involves a wide variety of activities, including: the organization of production, installation and reconstruction of equipment for the cleaning 
the gas dust flow chemical and biological pollutants emitted into the air, and reducing the impact of physical and biological factors on the air, the development of technology, the organization of production and use of materials, the use of methods and the introduction of technologies that prevent the occurrence, reduce the level of exposure or eliminate the factors of air pollution; construction of pilot and pilot plants for the development of methods for the purification of gases emitted from sources of harmful emissions into the atmosphere; development and production of control systems and devices and equipping them with stationary sources of emissions of harmful substances into the atmosphere and control points and monitoring of atmospheric air pollution; construction and equipment of checkpoints for checking and reducing the toxicity of the exhaust gases of vehicles; development, organization of production of devices for purification of exhaust gases of engines and their equipping of vehicles; carrying out works on the inventory of sources of environmental pollution (On approval of the list of activities related to nature conservation measures, 1996).

Insufficient effectiveness of the existing mechanism for financing environmental measures is explained by the following reasons: imperfection of the legal framework regarding state support for environmental activities; low level of budgetary discipline in the field of environmental protection; the imbalance of the revenue and expenditure parts of the system of financing environmental measures; insufficient information on the real (true) value of environmental damage to society; instability of the financial and tax system; instability of the organizational mechanism of environmental regulation; limited financial resources and low efficiency in the use of funds for environmental measures; insufficient concentration of funds in priority areas, dispersion of funds by other funds and activities that do not solve major environmental problems.

The environmental tax itself must provide, on the one hand, special mechanisms for the taxation of environmentally harmful products (negative incentives) and, on the other, a wide range of tax benefits for those business entities and legal entities that use resources and energy-saving technologies, develop environmentally friendly production, improve the quality of the environment. The advantage of this tool is its immediate impact on the manufacturer (compared to legislation, development and adoption of which takes time) and the opportunity for the state to generate additional revenue that can be used to reduce other types of taxes, to implement environmental protection projects, to subsidize environmentally friendly manufacturing, aid to developing countries, and more. Today, the method of linear dependence of the amount of pollution charge on the amount of emissions and the size of the pollutant's profit is used in Ukraine. It is advisable to abandon this method because in practice, there are cases where the amount of the mandatory pollution charge is several times higher than the profit of the polluting enterprise. Therefore, the collection of pollution charges will be neither tangible nor cost-effective for such enterprises, since even reducing emissions will not reduce the amount of pollution charges. The experience of many countries in the world shows that the effectiveness of pollution and environmental tax payments depends on the average marginal cost to producers of reducing pollution. It is time to scientifically develop and lay the basis of calculations for the dependence of the pollution charge on the total costs of polluting enterprises to reduce pollution. 
It is therefore our opinion today the expenditures of the state budget of Ukraine for the protection of the atmospheric air and the environment as a whole should correspond to the tax revenues from the environmental tax in the regions of Ukraine. Otherwise, it can be argued that the environmental tax rates are not substantiated, namely that they are underestimated in certain regions, since their size does not provide the revenue part of the relevant budget at a sufficient level to fulfill the tasks assigned to them. Since the amount of the environmental tax paid is a direct reflection of the damage caused to the environment, and the introduction of this tax is intended to improve and restore the environmental component, theoretically the amount of budgetary costs for such restoration should not be less than the amount paid in this territory of the environmental tax. Global experience in environmental regulation shows that, in order to protect the interests of citizens and national producers, the global community is trying to coordinate its actions in the field of environmental taxation. A feature of environmental taxation is that environmental progress is achieved with the least loss for the economy compared to other regulatory instruments. The use of price incentives through higher-tax "harmful production" taxation, compared to "clean" alternatives, has a more flexible response from producers and consumers. Taxes stimulate behavior change through a system of incentives, not coercion. If the amount of penalties for indifference to the environmental problems of environmental managers is less than the cost of compliance, then the government, by changing the rates of environmental taxes, their structure and payment rules, should make them larger. This will have the effect of reducing pollutant emissions, increasing the cost of innovation and technological improvements.

\section{Principal Steps to Prevent Air Pollution in Ukraine}

Given that Ukraine is a geographic part of Europe, it must, for objective reasons, be energetically and economically integrated into the European Union with further membership in this organization. This thesis is reinforced by the fact that close relations between Ukraine and the EU are established in the political, economic and energy spheres (Kurylo V., Gyrenko I. etc., 2019). In the context of promoting energy security and the effectiveness of environmental protection measures to prevent air pollution in Ukraine, fiscal policy plays an important role, which is an important tool for managing the economy because of its ability to influence the stabilization of economic growth and avoid economic crises.

The solution of some environmental pollution problems requires cooperation at state, national and international levels) (Hossain et al. 2014). Ukraine's ratification of the Convention on Long-range Transboundary Air Pollution puts additional requirements on the state to comply with environmental legislation on atmospheric air protection, to implement environmental measures and monitoring practices in line with those adopted in EU countries (Convention on Long-range Transboundary Air Pollution, 1979). Air pollution does not recognize geographic boundaries, some pollutants can travel great distances affecting air quality and public health

Meanwhile, air quality policy is not only an environmental objective, but also an economic opportunity and a driver for innovation, as strengthening the air quality regime can actually benefit competitiveness. 
Therefore, the effectiveness of fiscal policy depends to a large extent on environmental policy in the country. Effective functioning of the whole nature protection activities system is impossible without effective management, which plays a leading role in view of the need to reduce the impact of the negative effects of the energy sector and create the right conditions for the life of the population. One of the problems of the state and local authorities is that they often fail to integrate ecological understanding into their decisions; such failure also poses serious risks to the global. Environmental governance is improved through mobilizing consensus and formulating environmental policy, developing international environmental law and supporting international initiatives.

Today, it is important for Ukraine to radically change the situation with regard to environmental taxation and to adopt global experience in order to improve the use of those environmental fiscal instruments and to build effective environmental policies. The main goal is not necessary to find the single best explanation for a social-ecological problem, but rather to unravel a range of different understandings as a basis for further exploration and learning. In this respect, minimizing and preventing the emission of harmful substances into the atmosphere through the application of environmental filters by industrial enterprises, the introduction of new standards for industry, the modernization of obsolete equipment, the transition to the operation of environmental transport, and household appliances recycling (incineration of household waste), implementation of integrated "green" alternatives that would be useful not only for waste but also for human health (for example, to motivate people to use bicycles as it is beneficial to the environment as well as to well-being), to increase energy efficiency and to the use of renewable energy through increased environmental and fiscal incentives. We believe that the Ukrainian authorities should act now to prevent a recurrence of the crisis, such as the Chernobyl disaster. Also for our opinions a series of interventions are important for restoring prosperity, support and greater stability in the future. This requires the creation of effective air quality management, where monitoring, both of the state of the environment and of the level of implementation of EU environmental law is crucial.

Setting air quality standards will allow you to control, evaluate and manage atmospheric air quality, which will protect the health of the population, vegetation and ecosystems. It is also necessary to develop a control strategy to reduce air pollution. For the main steps in developing a control strategy need to determine priority pollutants (the pollutants of concern for a specific location will be based on the nature of the associated health or environmental effects and the severity of the air quality problem in that area); identify measures to control sources of pollution and compliance with the air quality standards, identify effective pollution prevention and control strategies, develop global emissions inventories and develop the next generation regulatory and compliance strategies, involve the public.

Financing of all environmental measures should be aimed at preserving and restoring the natural state of the atmospheric air, creating favorable conditions for life, ensuring environmental safety and preventing the harmful effects of the atmospheric air on human health and the environment.

By introducing new tools for environmental and fiscal stimulation of business entities, Ukraine needs to establish a clear strategy for the society to achieve its goals and to have 
a clear administration in this area, to ensure personal security of citizens, to overcome the organizational and financial foundations of criminal activities, corruption, to increase the effectiveness of the state and local authorities based on openness and transparency of decision-making and public scrutiny of their implementation. Achieving sustainable development at the local level, above all, requires efforts to strengthen the role of local communities in the process of achieving the goal, which can be achieved by increasing their authority to impose sanctions on environmental pollutants and economically promoting responsible behavior, introducing inclusive and informative programs. educational measures for sustainable consumption and production will help to create appropriate prudent behaviors and practices among the population. The experience of many European countries demonstrates how pressure from public opinion and nongovernmental organizations has led to discussions and a positive decision to take measures to protect the air. For example, in that way led to the introduction of the Austrian landfill tax, provided inspiration for ecological fiscal transfers in Portugal and biodiversity offsetting schemes in Germany.

\section{Conclusions}

Air quality remains a major environmental threat to public health and is largely the result of effective state environmental policies and funding of environmental measures. The instruments and mechanisms of the legal, economic, institutional, regulatory, organizational system and the system of authorization in Ukraine in most only partially corresponds to the established approaches and elaborated standards for environmental protection activities of EU countries. This applies to both the environmental law system and its enforcement mechanisms, approaches to the organization and implementation of environmentally responsible economic and business activities. Domestic legislation on the protection of atmospheric air should be harmonized in accordance with the EU standards, which must be carried out in three directions: legislative (legal field), regulatory (norms, standards, technical regulations), technological (implementation of "clean" and energy-saving technologies, etc.). Taking into consideration existing data and issues affecting our air quality, Ukraine should in a timely manner to earmark strategy for the future to provide clean air for future generations, implemented measures to reduce air pollution that can significantly improve overall air quality with positive environmental and health impacts.

\section{References}

Convention on Long-range Transboundary Air Pollution, 13.11.1979. Available at: http://www.unece.org/fileadmin//DAM/env/lrtap/lrtap_h1.htm.

Di Turo, F., Proietti, C., Screpanti, A., Fornasier, M. F., Cionni, I., Favero, G., \& De Marco, A. (2016). Impacts of air pollution on cultural heritage corrosion at European level: What has been achieved and what are the future scenarios. Environmental Pollution, 218, 586-594. https://doi.org/10.1016/j.envpol.2016.07.042.

Directive 2008/50/EC of the European Parliament and of the Council of 21 May 2008 on ambient air quality and cleaner air for Europe OJ L 152, 11.6.2008, p. 1-44. Available at: https://eurlex.europa.eu/legal-content/EN/ALL/?uri=CELEX:32008L0050. 
Environmental performance Index report 2018. Available at: https://epi.envirocenter.yale.edu/2018/report/category/hlt.

European Commission (2010). Europe 2020: A strategy for smart, sustainable and inclusive growth. Communication from the Commission. Brussels, 2010, 03 March. 32 p. Available at: https://eurlex.europa.eu/LexUriServ/LexUriServ.do?uri=COM:2010:2020:FIN:EN:PDF.

Eurostat. Environmental tax revenues[env_ac_tax] Available at: https://appsso.eurostat.ec.europa.eu/nui/show.do?dataset=env_ac_tax\&lang=en.

Gulac, O., Dubchak, L., Iarmolenko, I., \& Yanchuk, J. (2019). Cooperation of Ukraine and the European Union in the Ecological Sector: Directions and Prospects. European Journal of Sustainable Development, 8(1), 22. https://doi.org/10.14207/ejsd.2019.v8n1p22

Hossain, K., \& Rao, A. R. (2014). Environmental Change And It's Affect. European Journal of Sustainable Development, 3(2), 89. https://doi.org/10.14207/ejsd.2014.v3n2p89.

Ministry of Energy and Environment Protection of Ukraine (2019). Top 100 Largest Enterprises of Pollutants, 11.12.2019 Available at: https://menr.gov.ua/news/34251.html.

On Air Protection: Law of Ukraine of 16.10 .1992 № 2707-XII. Available at: https://zakon.rada.gov.ua/laws/show/2707-12.

On approval of the list of activities related to nature conservation measures: The Decree of Ukraine: The Cabinet of Ministries of Ukraine, 17.09.1996, № 1147 Available at: https://zakon.rada.gov.ua/laws/show/1147-96-\%D0\%BF.

Shulga, I., Kurylo, V., Gyrenko, I., \& Savych, S. (2019). Legal Regulation of Energy Safety in Ukraine and the European Union: Problems and Perspective. European Journal of Sustainable Development, 8(3), 439. https://doi.org/10.14207/ejsd.2019.v8n3p439.

Some Issues of Implementation of the Financing Agreement on the Support to the Implementation of the National Environmental Policy Strategy of Ukraine: The Decree of Ukraine. The Cabinet of Ministries of Ukraine, 17.08.2011, \# 877. Available at: https://zakon.rada.gov.ua/laws/show/877-2011-\%D0\%BF.

The State Treasury Service of Ukraine (2018). Annual Report on Implementation of the State Budget of Ukraine for 2018. Available at: https://www.treasury.gov.ua/ua/file-storage/richnij-zvit-provikonannya-derzhavnogo-byudzhetu-ukrayini-za-2018-rik?page $=4$.

World Health Organization (2019). Ten threats to global health in 2019. Available at: https://www.who.int/vietnam/news/feature-stories/detail/ten-threats-to-global-health-in-2019. 